\title{
PLANT POLYSACCHARIDE DEGRADING ENZYME SYSTEM OF THERMOBIFIDA CELLULOSILYTICA TB100 REVEALED BY DE NOVO GENOME PROJECT DATA
}

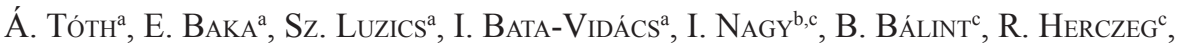

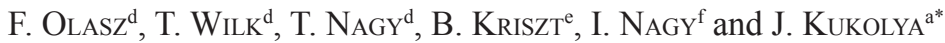 \\ a Department of Applied and Environmental Microbiology, Research Institute of Agro-Environmental Sciences, \\ National Agricultural Research and Innovation Centre, H-1022 Budapest, Herman Ottó út 15. Hungary \\ bInstitute of Biochemistry, Biological Research Centre of the Hungarian Academy of Sciences, \\ H-6726 Szeged, Temesvári krt. 62. Hungary \\ 'SeqOmics Biotechnology Ltd., H-6782 Mórahalom, Vállalkozók útja 7. Hungary \\ 'Laboratory of Microbiology; Agricultural Biotechnology Institute, National Agricultural Research and Innovation \\ Centre, H-2100 Gödöllö, Szent-Györgyi Albert utca 4. Hungary \\ eDepartment of Environmental Safety and Ecotoxicology, Institute of Aquaculture and Environmental Safety, \\ Faculty of Agricultural and Environmental Sciences, Szent István University, \\ H-2100 Gödöllő, Páter Károly utca 1. Hungary \\ fDepartment of Molecular Structural Biology, Max Planck Institute of Biochemistry, Am Klopferspitz 18. \\ D-82152 Martinsried. Germany
}

(Received: 16 September 2015; accepted: 20 January 2016)

Thermobifidas are thermophilic, aerobic, lignocellulose decomposing actinomycetes. The Thermobifida genus includes four species: T. fusca, T. alba, T. cellulosilytica, and T. halotolerans. T. fusca YX is the far best characterized strain of this taxon and several cellulases and hemicellulases have been cloned from it for industrial purposes targeting paper industry, biofuel, and feed applications. Unfortunately, sequence data of such enzymes are almost exclusively restricted to this single species; however, we demonstrated earlier by zymography that other $T$. alba and T. cellulosilytica strains encode the same enzyme sets. Recently, the advances in whole genome sequencing by the use of next generation genomics platforms accelerated the selection process of valuable hydrolases from uncharacterized bacterial species for cloning purposes. For this purpose T. cellulosilytica $\mathrm{TB} 100^{\mathrm{T}}$ type strain was chosen for de novo genome sequencing. We have assembled the genome of T. cellulosilytica strain TB100 ${ }^{\mathrm{T}}$ into 168 contigs and 19 scaffolds, with reference length of 4327869 bps, 3589 putative coding sequences, 53 tRNAs, and 4 rRNAs. The analysis of the annotated genome revealed the existence of 27 putative hydrolases belonging to 14 different glycoside hydrolase $(\mathrm{GH})$ families. The investigation of identified, cloned, and heterologously multiple cellulases, mannanases, xylanases, and amylases may result in industrial applications beside gaining useful basic research related information.

Keywords: de novo genome project, glycoside hydrolyses, Thermobifida, cellulases, hemicellulases, amylases

Four species, Thermobifida fusca, T. alba (ZHANG et al., 1998), T. cellulosilytica (KuKOLYA et al., 2002), and T. halotolerans (YANG et al., 2008), constitute the Thermobifida genus. Several cellulases and hemicellulases have been cloned from the best characterized T. fusca YX strain. This actinomycete utilizes various plant cell wall polymers, including cellulose as the major carbon source, and secretes multiple cellulases: four endoglucanases (Ce19B, Cel6A, Cel5A, Cel5B), two exoglucanases (Cel6B and Cel48A), and an endo/exoglucanase (Cel9A), which have been characterized in detail (GHANGAS \& WiLsOn, 1988; Irwin et al., 1998; LAO et

* To whom correspondence should be addressed. Phone: +36 1 796-0400/186; fax:+36 1 796-0449; e-mail: j.kukolya@cfri.hu

This is an open-access article distributed under the terms of the Creative Commons Attribution-NonCommercial 4.0 International License (https://creativecommons.org/licenses/by-nc/4.0/), which permits unrestricted use, distribution, and reproduction in any medium for non-commercial purposes, provided the original author and source are credited, a link to the CC License is provided, and changes - if any - are indicated. 
al., 1991; Jung et al., 1993; PostA et al., 2004). Unfortunately, sequence data of these enzymes are almost exclusively restricted to this single species. The complete genome-sequence of $T$. fusca strains were published in 2007 and 2013 (LyKIDIs et al., 2007; TóTH et al., 2013). Earlier we demonstrated by zymography that $T$. cellulosilytica strains encode the same cellulase enzyme set as T. fusca TM51 (KuKOLYA et al., 2002). Despite the high scientific and industrial potential of hydrolases of $T$. cellulosilytica, there is only one paper dealing with a cutinase from this species (HERRERo et al., 2013).

For facilitating the research on T. cellulosilytica plant polysaccharide degrading enzyme system, the full genome sequencing seems the most appropriate and fastest approach. The Genomes OnLine Database (GOLD: www.genomesonline.org) (REDDY et al., 2015) currently holds 47509 bacterial genome projects, 3948 of them being completed with closed genomes, while 22739 of them are completed yielding permanent draft. It is worth noting how small fraction of the genome projects reaches complete closure. Despite the massive simplification and cost reduction offered by NGS technologies, assembling a bacterial genome into completely closed chromosome(s) is still a tedious work. Large repetitive elements (rRNA clusters, prophage regions, transposable elements, etc.) are difficult if not impossible regions for the assembler software to accurately resolve that results gaps in the draft genome. Finishing a draft to completely closed sequences requires classic molecular (low throughput) biology techniques (PCR) and multiple rounds of capillary electrophoresis sequencing.

Our aim was to generate a good quality, scaffolded draft genome of Thermobifida cellulosilytica strain that can be later subjected to automated annotation yielding a comprehensive list of biochemical features of the organism. As the main feature of thermobifidas is the outstanding cellulose degradation capacity, we focused on the identification of the main plant polysaccharide degrading enzyme complexes, namely cellulases, hemicellulases, and amylases.

\section{Materials and methods}

\subsection{Chemicals}

Unless otherwise indicated, all chemicals herein used were of analytical-grade and purchased from Sigma-Aldrich Ltd. (Budapest, Hungary).

\subsection{Microorganisms}

Ten Thermobifida strains were used in this study. Thermobifida fusca TM51, TB107, T. alba $\mathrm{K} 51, \mathrm{~K} 52$, and T. cellulosilytica $\mathrm{K} 21, \mathrm{~TB}_{100}^{\mathrm{T}}$, TB108, and TB110 were isolated earlier from the hot region of manure compost (KuKOLYA et al., 1997). T. fusca $27730^{\mathrm{T}}$ and Thermobifida alba $43795^{\mathrm{T}}$ were purchased from American Type Culture Collection (ATTC) and Deutsche Sammlung von Mikroorganismen und Zellkulturen GmbH (DSMZ), respectively.

\subsection{Endoglucanase zymography for selecting T. cellulosilytica strain for de novo genome project}

1.3.1. Production of crude cellulase enzyme samples for zymography. Thermobifida strains were grown on basal medium $\left(\mathrm{NaNO}_{3}, 1.0 \mathrm{~g} ; \mathrm{KCl}, 0.3 \mathrm{~g} ; \mathrm{MgSO}_{4} \cdot \mathrm{H}_{2} \mathrm{O}, 0.5 \mathrm{~g} ; \mathrm{K}_{2} \mathrm{HPO}_{4}, 1.0 \mathrm{~g}\right.$; yeast extract, $0.5 \mathrm{~g}$; peptone, $0.5 \mathrm{~g}$; distilled water, $1000 \mathrm{ml}, \mathrm{pH} 7.6$ ) containing $0.2 \%$ carboxymethyl cellulose. For endoglucanase enzyme production, liquid cultures were shaken 
at 220 r.p.m. for $72 \mathrm{~h}$ at $50{ }^{\circ} \mathrm{C}$. After centrifugation, supernatants were treated with EtOH, reaching $40 \%$ ethanol concentration. The precipitates - representing the crude enzyme fraction - were separated by centrifugation at $15000 \times g$ for 15 min at $4{ }^{\circ} \mathrm{C}$.

1.3.2. SDS-PAGE zymography. SDS-polyacrylamide slab gels $(0.75 \mathrm{~mm}$ thick) were prepared according to the method of O'FARRELL (1975). The 10\% acrylamide separating gel contained $0.1 \% \mathrm{CMC}$ as substrate to test endoglucanase activity (PostA et al., 2004). Aliquots of $5 \mu \mathrm{l}$ ethanol precipitated crude enzyme samples were boiled in loading buffer for 5 min. Gels were renatured after separation by washing twice with isopropanol solution containing $(25 \%, \mathrm{~V} / \mathrm{V})$ phosphate buffer $(0.1 \mathrm{M}, \mathrm{pH} 7.0)$ at room temperature (RT). After this, two subsequent washing steps with phosphate buffer $(0.1 \mathrm{M}, \mathrm{pH} 7.0)$ were applied and gels were incubated at $50{ }^{\circ} \mathrm{C}$ for $30 \mathrm{~min}$ and were stained for visualizing active enzyme bands with $1 \%$ Congo-red solution.

\subsection{De novo genome sequencing}

Genomic DNA from T. cellulosilytica TB100 $10{ }^{\mathrm{T}}$ was prepared as previously described (BÉKI et al., 2003). Mate-pair genomic library kit (Illumina) was used to construct a genomic library from T. cellulosilytica genomic DNA with template sizes between 3 and $6 \mathrm{~kb}$. Samples were sequenced on an Illumina MiSeq platfom using $2 \times 250$ cycles and V2 sequencing chemistry. Mate-pair junction adapter was identified and removed from the raw reads according to the manufacturer's recommendations (Illumina). De novo assembly of the processed MP reads was carried out with Mira V 4.0.2 (CHEVREUX et al., 1999) and contigs were scaffolded using SSpace 3.0. (BoEtzer et al., 2011); draft genome was annotated using RAST (AzIz et al., 2008).

\subsection{Identification and characterization of polysaccharide hydrolases}

For characterizing the main plant polysaccharide degrading enzyme sets (cellulases, hemicellulases, and amylases) from the annotated genome, sequences were analysed by using the BLAST server (MADDEN et al., 1996). Amino acid sequence and domain structure of the selected glycoside hydrolases were determined by Swiss-Prot, EMBL and NCBI database queries and by using the Pfam (Bateman et al., 2002) and InterPro (Mitchell et al., 2015) bioinformatics servers.

\section{Results and discussion}

\subsection{Endoglucanase zymography to select $\mathrm{T}$. cellulosilytica strain for de novo genome project}

Crude cellulases of ten different Thermobifida strains belonging to T. fusca, T. alba, and T. cellulosilytica were investigated by endoglucanase zymography. As clearly can be seen in Figure 1, endoglucanases produced by Thermobifida strains are extremely heat stable, as these enzymes remained active even after $5 \mathrm{~min}$ boiling in loading buffer. According to the band pattern, the three Thermobifida species produce unique and slightly different endoglucanases. The number of endoglucanase bands is higher (5-7) in the case of T. alba and $T$. fusca than for T. cellulosilytica (3-6). According to the multiplicity of endoglucanase zymogram, T. cellulosilytica $\mathrm{TB} 100^{\mathrm{T}}$ was chosen for the de novo genome project. 


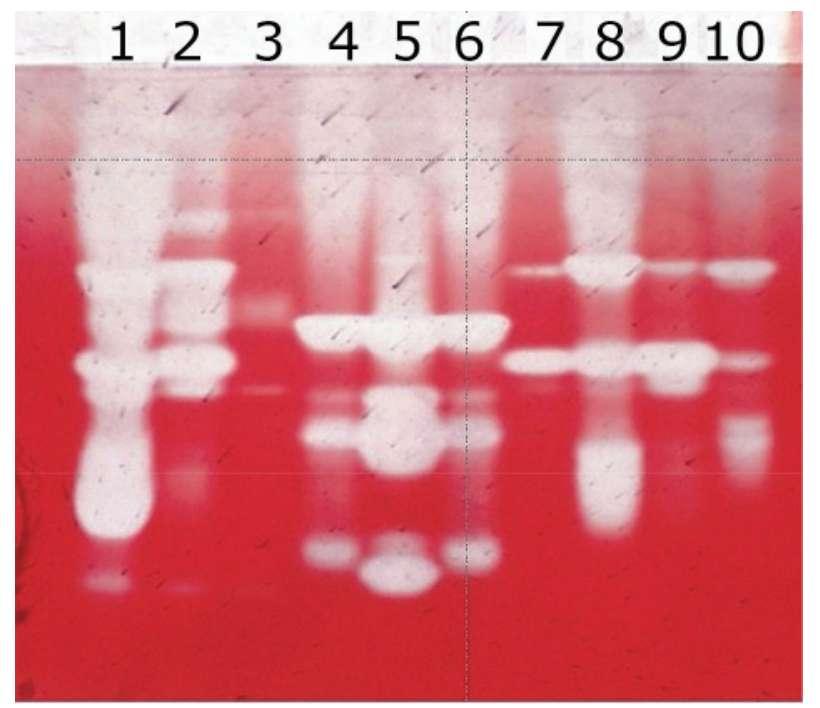

Fig. 1. SDS-PAGE endoglucanase zymogram of Thermobifida strains. Active endoglucanases were visualized by Congo-red staining. Samples: 1: T. alba 43795 ; 2: K51; 3: K52; 4: T. fusca 27730'; 5: TM51; 6: TB107; 7: T. cellulosilytica K21; 8: T. cellulosilytica $\mathrm{TB}_{100}^{\mathrm{T}}$; 9: TB108; 10: TB110

\subsection{De novo genome sequencing}

We have assembled the genome of T. cellulosilytica strain $\mathrm{TB}_{100^{\mathrm{T}}}$ into 168 contigs and 19 scaffolds, with reference length of 4327869 bps, 3589 putative coding sequences, 53 tRNAs, and 4 rRNAs. The analysis of the annotated genome revealed the existence of 27 putative hydrolases belonging to 14 different glycoside hydrolase (GH) families.

This whole-genome shotgun project has been deposited at DDBJ/EMBL/GenBank under the accession numbers: BioProject; PRJNA289053, BioSample; SAMN03840822, NCBI Accession; LGEM00000000.

2.2.1. Cellulases. The cellulase enzyme system of $T$ cellulosilytica (Fig. 2) found in our genome project is identical to the well-characterized glycoside hydrolases of $T$. fusca (WiLson, 2004). Characteristic features of the enzymes are summarized in Table 1. Four glycoside hydrolase enzyme sets were found that belonged to four independent families. Each of the enzyme sets consisted of 4 endoglucanases (endo- $\beta$-1,4-glucanase/cellulase, EC 3.2.1.4), Cel5A, Cel5B, Cel6A, Cel9B (Irwin et al., 1993; Jung et al., 1993; Zhang \& Wilson, 1997; Posta et al., 2004), one processive endoglucanase, Cel 9A (SAKON et al., 1997), and two cellulose chain reducing cellobiohydrolases. One of them (Cel 48A, EC 3.2.1.176) is acting on the reducing, the other one, Cel6B (cellobiohydrolase, EC 3.2.1.91), is on the nonreducing end (ZHANG et al., 1995; BARR et al., 1996). 


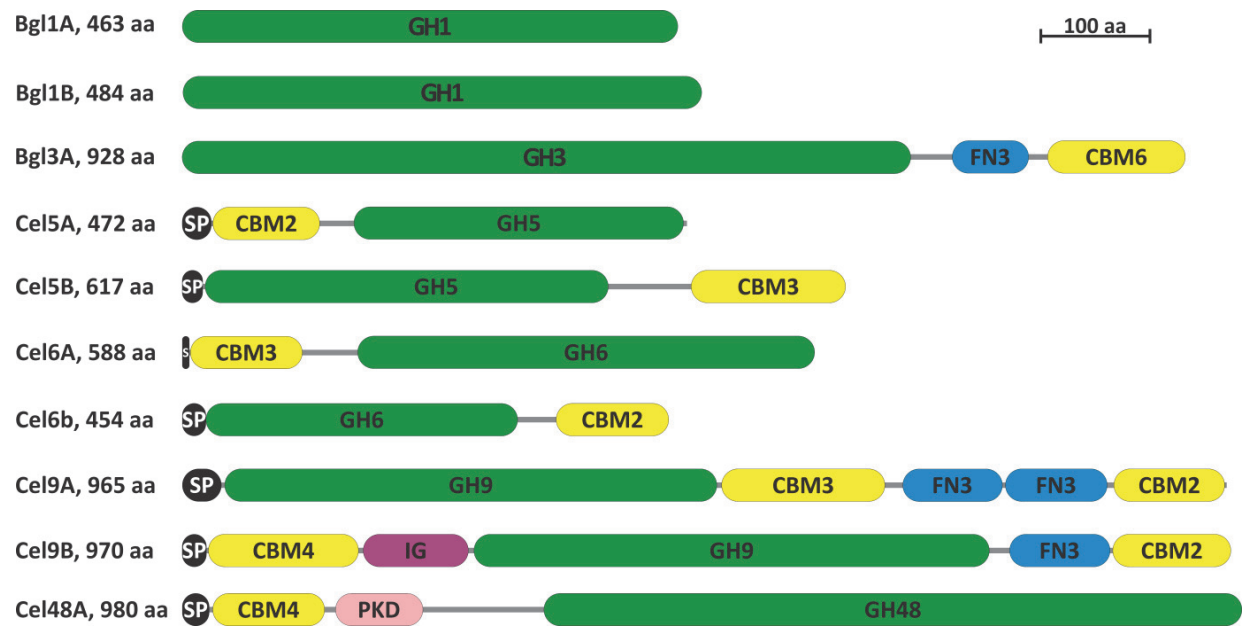

Fig. 2. Domain structure of cellulases encoded by T. cellulosilytica TB100T . SP: signal peptide; CBM: carbohydrate modules; FN3: fibronectin type domain; IG: immune globulin like domain; PKD: polycystic kidney disease protein like domain

A common feature of extracellular enzymes of T. cellulosilytica is the complex domain structure, where both catalytic domain and hydrophobic substrate binding modules, like CBD 2, 3, and 6 types, FN3 and IG modules, and PKD domains are present (Figs 2-5). Additionally, linker sequences with characteristic motives can be found between domains of cellulase enzymes except enzymes of the GH9 family (Table 1). These might have a role in post-translational modifications providing cleavage sites for specific proteases. By this mechanism there is a possibility for the representation of "only catalytic site" enzymes that can hydrolyse shorter, water soluble polymers/oligosaccharides. Such maturation mechanism can be responsible for the increased number of active bands on the zymogram (Fig. 1), since more bands are visualized than could be expected after the number of endoglucanases encoded on the genome.

There were also two intracellular GH1 family beta-glucosidases (EC 3.2.1.21) and a GH3 family hypothetical glucan 1,3- $\beta$-glucosidase (EC 3.2.1.58) found. Interestingly, the latter enzyme seems to be intracellularly located in spite of encoding for complex polysaccharide binding domains (FN3 and CBD6).

2.2.2. Hemicellulases. The identified hemicellulases from the annotated genome are shown in Figure 3, their features are summarized in Table 1. The hemicellulases of T. cellulosilytica show total homology to the xylanases, mannanases, and xyloglucanases identified in T. fusca genome project. The polysaccharide binding domains of this enzyme group are less diverse compared to the cellulases: the extracellular enzymes belong to CBM2 type without exception. Interestingly, a TAT signal sequence of GH74 xyloglucanase enzyme (EC 3.2.1.151), which refers to the presence of transport system specific for Streptomyces, was identified. This enzyme was formerly described in T. fusca (IRwIN et al., 2003). The mannanases among the hemicellulases consist of an intracellular GH2 mannosidase and an extracellular GH5 endomannanase. From T. fusca only the mannosidase enzyme was 
TÓTH et al.: THERMOBIFIDA CELLULOSILYTICA GENOME

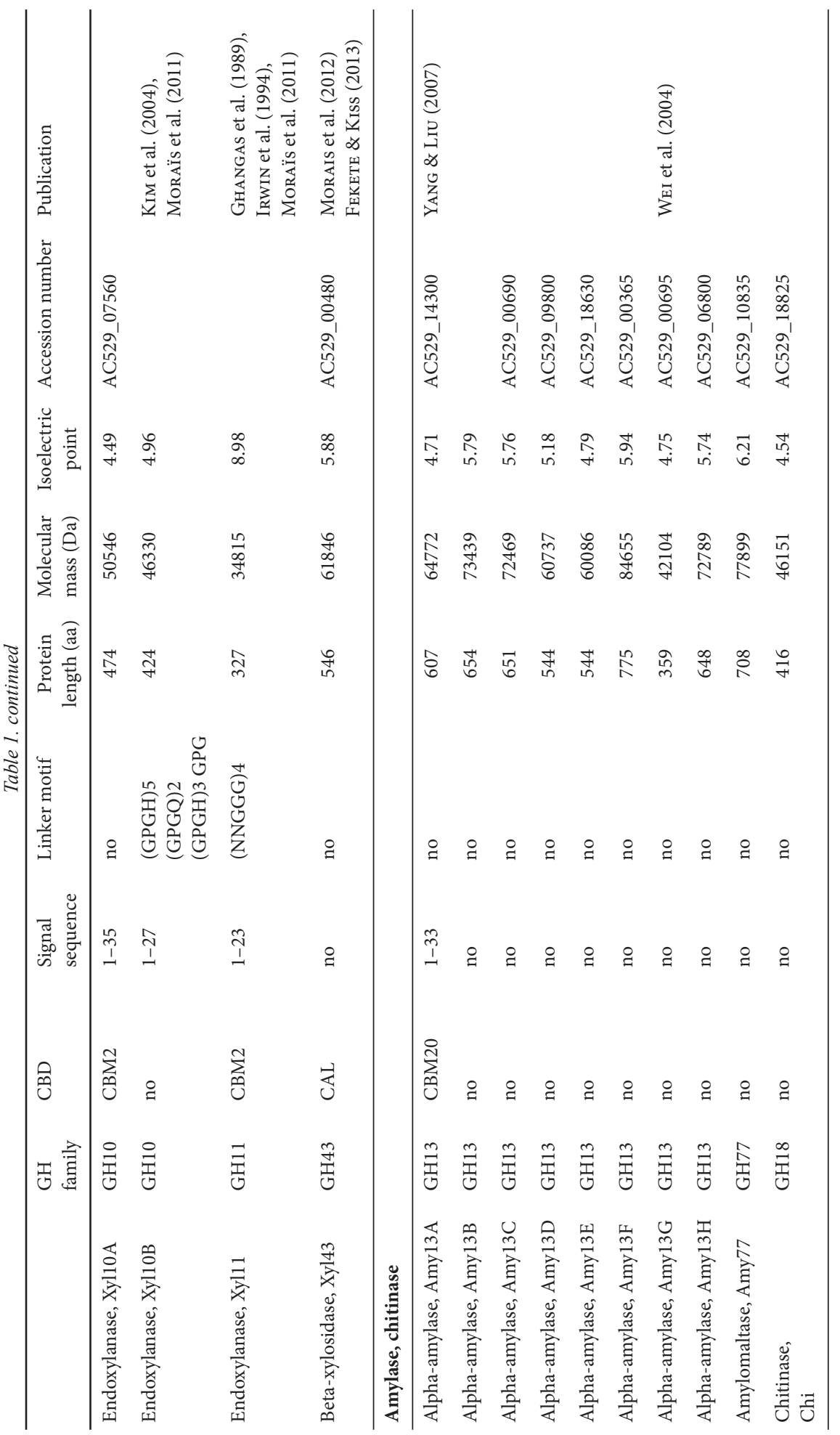


described so far (BéKI et al., 2003), the endomannanase has not been published yet. $T$. cellulosilytica encodes the following xylanases: two GH10 and one GH11 extracellular endoxylanases (endo-1,4- $\beta$-xylanase (EC 3.2.1.8) and one GH43 intracellular beta-xylosidase (EC 3.2.1.37)). Although the first Thermobifida crystallized hydrolase, a GH11 endoxylanase, was published in 1996 (HILGE et al., 1996) and after that a GH10 endoxylanase from T. alba was published (Blanco et al., 1997), the Xyl10B enzyme has not yet been described.

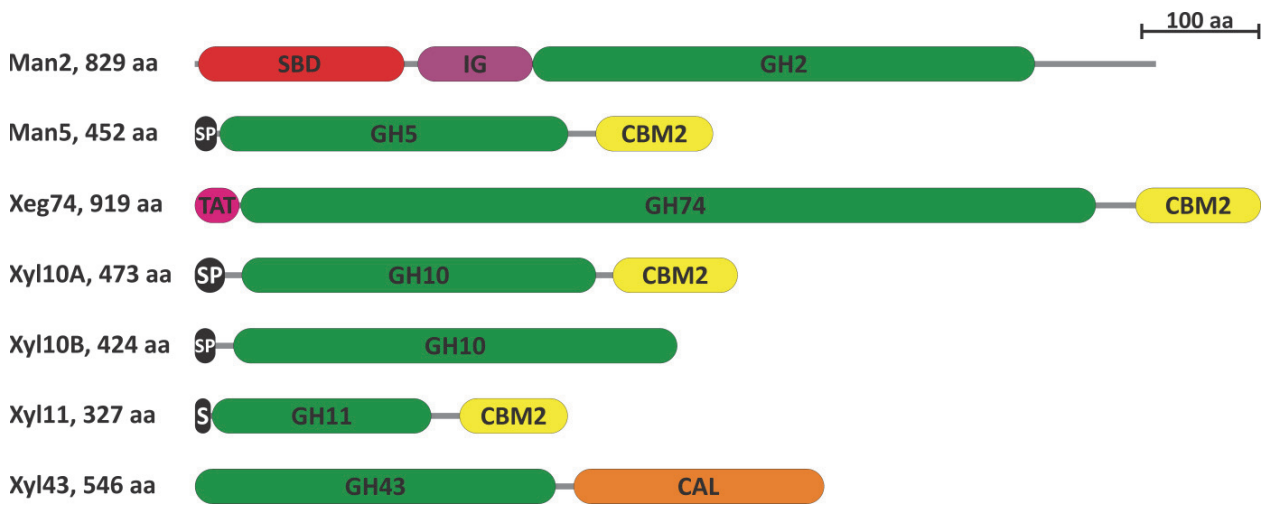

Fig. 3. Domain structure of hemicellulases encoded by T. cellulosilytica TB100 ${ }^{\mathrm{T}}$. SP: signal peptide; TAT: streptomyces transport signal; CBM: carbohydrate modules; IG: immune globulin like domain; CAL: carbohydrate binding; SBD: sugar binding domain

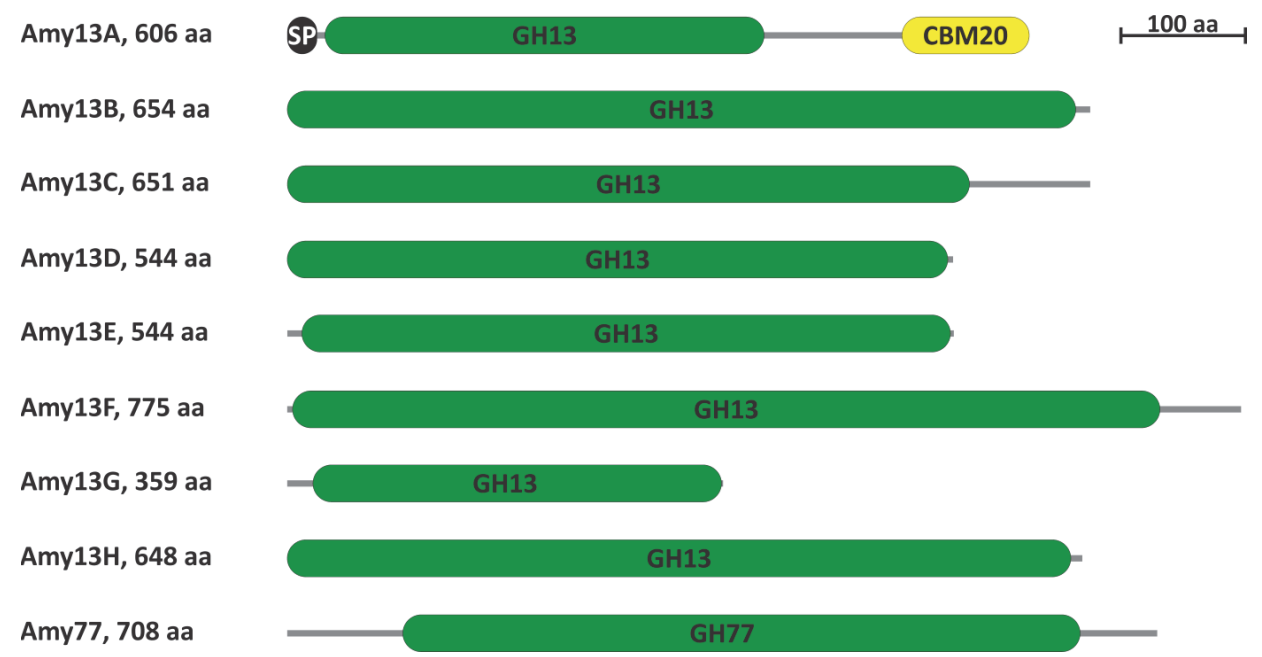

Fig. 4. Domain structure of amylases encoded by T. cellulosilytica TB100T . SP: signal peptide; CBM: carbohydrate module 


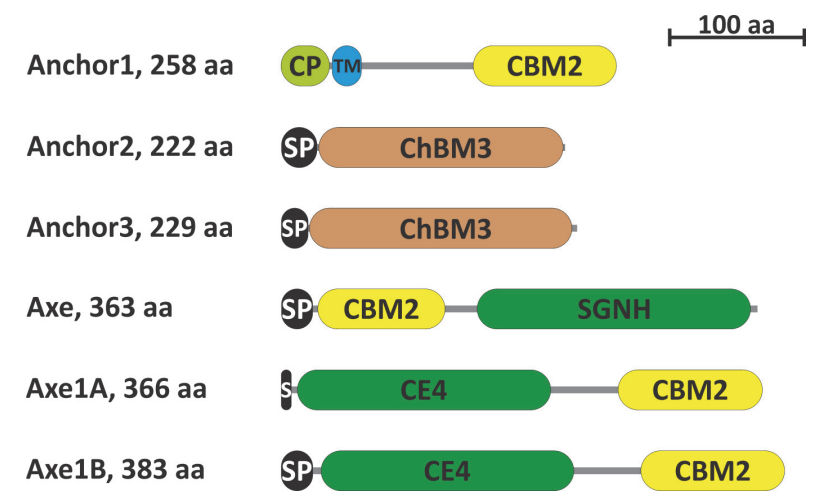

Fig. 5. Domain structure of proteins harbouring carbohydrate binding modules produced by T. cellulosilytica TB100 ${ }^{\mathrm{T}}$. SP: signal peptide; CP: cytoplasmic module; TM: transmembrane protein; ChBM: chitin binding module; CBM: carbohydrate module; SGNH: hydrolase domain; CE: carbohydrate esterase domain

2.2.3. Amylases. The amylase system of $T$. cellulosilytica consists of 9 identified enzymes, one of which (amylomaltase or 4- $\alpha$-glucanotransferase, EC 2.4.1.25) is from the family GH77, and 8 are from the family GH13. The single extracellular member of the system is enzyme Amy13A, bearing a CBM20 amylose binding domain N-terminally (Fig. 4). The high number of intracellular GH13 enzymes presumes a distinct function, which is supported by the extremely wide substrate spectrum, the mechanism of actions, and prevalence of this hydrolase family among bacteria (according to the Cazy database, 24605 genes coding this enzyme has been identified to this day): $\alpha$-amylase (EC 3.2.1.1); pullulanase (EC 3.2.1.41); cyclomaltodextrin glucanotransferase (EC 2.4.1.19); cyclomaltodextrinase (EC 3.2.1.54); trehalose-6-phosphate hydrolase (EC 3.2.1.93); oligo- $\alpha$-glucosidase (EC 3.2.1.10); maltogenic amylase (EC 3.2.1.133); neopullulanase (EC 3.2.1.135); $\alpha$-glucosidase (EC 3.2.1.20); maltotetraose-forming $\alpha$-amylase (EC 3.2.1.60); isoamylase (EC 3.2.1.68); glucodextranase (EC 3.2.1.70); maltohexaose-forming $\alpha$-amylase (EC 3.2.1.98); maltotrioseforming $\alpha$-amylase (EC 3.2.1.116); branching enzyme (EC 2.4.1.18); trehalose synthase (EC 5.4.99.16); 4- $\alpha$-glucanotransferase (EC 2.4.1.25); maltopentaose-forming $\alpha$-amylase (EC 3.2.1.-); amylosucrase (EC 2.4.1.4); sucrose phosphorylase (EC 2.4.1.7); maltooligosyltrehalose trehalohydrolase (EC 3.2.1.141); isomaltulose synthase (EC 5.4.99.11); malto-oligosyltrehalose synthase (EC 5.4.99.15); amylo-a-1,6-glucosidase (EC 3.2.1.33); $\alpha$-1,4-glucan: phosphate $\alpha$-maltosyltransferase (EC 2.4.99.16).

The research on Thermobifida amylases is a neglected area, only two enzymes are mentioned in the literature: GH77 amylomaltase of Thermobifida fusca (YANG \& Liv, 2007) and a GH13 trehalose synthase (WEI et al., 2004).

2.2.4. CBM containing proteins. Five extracellular proteins containing carbohydrate binding modules could be identified in the annotated genome. Three of them are acetyl xylan esterases (EC 3.1.1.72) bearing one module of CBM2 in C- or N-terminal positions. There are also three proteins without catalytic domain, the first bearing the CBM2 module, bound to cell surface, indicated by its transmembrane region. The function of this protein could be similar to the cellulose anchoring protein of Streptomyces reticuli (WALTER et al., 1998). The other two show chitin binding module homology, the role of these is yet totally unknown in thermobifidas (Fig. 5). 


\section{Conclusions}

Thermobifida cellulosilytica strain TB100 ${ }^{\mathrm{T}}$ was chosen for de novo genome project based on the highest number of isoenzyme bands on endoglucanase zymogram. Strain $\mathrm{TB} 100^{\mathrm{T}}$ has a complex endoglucanase isoenzyme pattern like T. fusca and T. alba. According to the band pattern, the three Thermobifida species produce unique and slightly different endoglucanases. The good resolution of the endoglucanase zymogram enables the identification of unknown thermobifida isolates. The number of endoglucanase bands is higher (5-7) than the formerly described endoglucanases (Cel5A, Cel5B, Cel6A, Cel9A) of T. fusca YX strain (WiLson, 2004). The probable explanation could be found in the post-translational modifications of the modular enzymes, during which a protease splits the cellulases into a catalytic and a cellulosebinding domain, increasing the number of isoenzymes.

Based on the chosen T. cellulosilytica $\mathrm{TB} 100^{\mathrm{T}}$ de novo genome project, the genome shows great similarity to the two already available genomes of $T$. fusca. The assembled genome of T. cellulosilytica strain TB100 ${ }^{\mathrm{T}}$ contains 168 contigs and 19 scaffolds, with reference length of 4327869 bps. The T. cellulosilytica $\mathrm{TB} 100^{\mathrm{T}}$ genome size is larger by 0.7 Mbp than the T. fusca TM51 (То́тн et al., 2013) or YX (LyкіDIs et al., 2007) genomes. Despite the larger genome size, the complexity of the glycoside hydrolase system, taking part in the degradation of plant polysaccharides of $\mathrm{TB} 100^{\mathrm{T}}$ strain, is identical to T. fusca $\mathrm{YX}$ (WILSON, 2004) and TM51 strains (TótH et al., 2013), additional enzymes were not found. The analysis of the annotated genome revealed the existence of 27 putative hydrolases belonging to 14 different glycoside hydrolase (GH) families (CANTAREL et al., 2009). GH13 is the largest glycoside hydrolase family in $\mathrm{TB} 100^{\mathrm{T}}$, with eight enzymes predicted to exhibit mainly dextran- and starch-degrading functions. Thermobifidas may become important industrial strains due to their thermostable and robust polysaccharide-degrading enzymes (Dhawan \& KaUR, 2007; Yang et al., 2007). The 83-87 percent amino acid sequence similarity of the glycoside hydrolases of Thermobifida species seems to be low enough to exhibit differences in the biochemical properties compared to other T. fusca enzymes. This can be clearly seen in the endomannanase zymograms of thermobifidas, where endomannanases of $T$. cellulosilytica strains proved to be the least heat stable. The genome project sequence of $T$. cellulosilytica makes the cloning of homologous, known enzymes of fusca-origin or unknown glycoside hydrolase enzymes not yet described from thermobifidas possible. Thus, enzymes encoded by Thermobifida cellulosilytica $\mathrm{TB} 100^{\mathrm{T}}$ may play a key role not only in pure science but in further industrial applications, like lignocellulose-based ethanol-producing projects, prebiotics production, and as sources for feed additives.

This work was supported by the Research Centre of Excellence-9878/2015/FEKUT project. István NAGY was supported by the János Bolyai Research Scholarship of the Hungarian Academy of Sciences.

\section{References}

Aziz, R.K., Bartels, D., Best, A.A., DeJongh, M., Disz, T., Edwards, R.A., Formsma, K., Gerdes, S., Glass, E.M., Kubal, M., Meyer, F., Olsen, G.J., Olson, R., Osterman, A.L., Overbeek, R.A., McNeil, L.K., Paarmann, D., Paczian, T., Parrello, B., Pusch, G.D., Reich, C., Stevens, R., Vassieva, O., Vonstein, V., Wilke, A. \& ZAGNiTKo, O. (2008): The RAST Server: rapid annotations using subsystems technology. BMC Genomics doi: $10.1186 / 1471-2164-9-75$ 
Barr, B.K., Hsieh, Y.L., Ganem, B. \& Wilson, D.B. (1996): Identification of two functionally different classes of exocellulases. Biochemistry, 35, 586-592.

Bateman, A., Birney, E., Cerruti, L., Durbin, R., Etwiller, L., Eddy, S.R., Griffiths-Jones, S., Howe, K.L., Marshall, M. \& Sonnhammer, E.L. (2002): The Pfam protein families database. Nucleic Acids Res., 30, 276-280.

BéKi, E., Nagy, I., Vanderleyden, J., Jager, S., Kiss, L., Fulop, L., Hornok, L. \& Kukolya, J. (2003): Cloning and heterologous expression of a beta-D-mannosidase (EC 3.2.1.25) encoding gene from Thermobifida fusca TM51. Appl. Environ. Microb., 69, 1944-1952.

Blanco, J., Coque, J.J., Velasco, J. \& Martin, J.F. (1997): Cloning, expression in Streptomyces lividans and biochemical characterization of a thermostable endo-beta-1,4-xylanase of Thermomonospora alba ULJB1 with cellulose-binding ability. Appl. Microbiol. Biot., 48, 208-217.

Boetzer, M., Henkel, C.V., Jansen, H.J., Butler, D. \& Pirovano, W. (2011): Scaffolding pre-assembled contigs using SSPACE. Bioinformatics, 27, 578-579.

Cantarel, B.L., Coutinho, P.M., Rancurel, C., Bernard, T., Lombard, V. \& Henrissat, B. (2009): The CarbohydrateActive EnZymes database (CAZy): an expert resource for glycogenomics. Nucleic Acids Res., 37, D233D238.

Chevreux, B., Wetter, T. \& Suhai, S. (1999): Genome sequence assembly using trace signals and additional sequence information. Computer Science and Biology: Proceedings of the German Conference on Bioinformatics, 99, 45-56.

Dhawan, S. \& Kaur, J. (2007): Microbial mannanases: an overview of production and applications. Crit. Rev. Biotechnol., 27, 197-216.

Fekete, C.A. \& Kiss, L. (2013): A new approach in the active site investigation of an inverting $\beta$-D-xylosidase from Thermobifida fusca TM51. Protein J., 32, 97-105. doi: 10.1007/s10930-013-9463-8.

Ghangas, G.S. \& Wilson, D.B. (1988): Cloning of the Thermomonospora fusca endoglucanase E2 gene in Streptomyces lividans: Affinity purification and functional domains of the cloned gene product. Appl. Environ. Microbiol., 54, 2521-2526.

Ghangas, G.S., Hu, Y.J. \& Wilson, D.B. (1989): Cloning of a Thermomonospora fusca xylanase gene and its expression in Escherichia coli and Streptomyces lividans. J. Bacteriol., 171, 2963-2969.

Herrero, E., Ribitsch, D., Dellacher, A., Zitzenbacher, S., Marold, A., Steinkellner, G., Gruber, K., Schwab, H. \& Guebitz, G.M. (2013): Surface engineering of a cutinase from Thermobifida cellulosilytica for improved polyester hydrolysis. Biotechnol. Bioeng., 110, 2581-2590.

Hilge, M., Gloor, S., Winterhalter, K., Zimmermann, W. \& Piontek, K. (1996): Crystallization and preliminary crystallographic analysis of two beta-mannanase isoforms from Thermomonospora fusca KW3. Acta Crystallogr. D., 52, 1224-1225.

Irwin, D.C., Jung, E.D. \& Wilson, D.B. (1994): Characterization and sequence of a Thermomonospora fusca xylanase. Appl. Environ. Microb., 60, 763-770.

Irwin, D.C., Shin, D.H., Zhang, S., Barr, B.K., Sakon, J., Karplus, P.A. \& Wilson, D.B. (1998): Roles of the catalytic domain and two cellulose binding domains of Thermomonospora fusca E4 in cellulose hydrolysis. J. Bacteriol., 180, 1709-1714.

Irwin, D.C., Cheng, M., Xiang, B., Rose, J.K. \& Wilson, D.B. (2003): Cloning, expression and characterization of a family-74 xyloglucanase from Thermobifida fusca. Eur. J. Biochem., 270, 3083-3091.

Irwin, D.C., Spezio, M., Walker, L.P. \& Wilson, D.B. (1993): Activity studies of eight purified cellulases: Specificity, synergism, and binding domain effects. Biotechnol. Bioeng., 42, 1002-1013.

IRwin, D.C., ZHANG, S. \& WiLson, D.B. (2000): Cloning, expression and characterization of a family 48 exocellulase, Cel48A, from Thermobifida fusca. Eur. J. Biochem., 267, 4988-4997.

Jung, E.D., LaO, G., Irwin, D., Barr, B.K., Benjamin, A. \& Wilson, D.B. (1993): DNA sequences and expression in Streptomyces lividans of an exoglucanase gene and an endoglucanase gene from Thermomonospora fusca. Appl. Environ. Microb., 59, 3032-3043.

Kim, J.H., IRwin, D. \& WiLson, D.B. (2004): Purification and characterization of Thermobifida fusca xylanase 10B. Can. J. Microbiol., 50, 835-843.

Kukolya, J., Dobolyi, C. \& Hornok, L. (1997): Isolation and identification of thermophilic cellulolytic actinomycetes. Acta Phytopathol. Hun., 32, 97-107.

Kukolya, J., Nagy, I., Láday, M., Tóth, E., Oravecz, O., Márialigeti, K. \& Hornok, L. (2002): Thermobifida cellulolytica sp. nov., a novel lignocellulose-decomposing actinomycete. Int. J. Syst. Evol. Micr., 52, 11931199 . 
Kumagai, Y., Kawakami, K., Mukaihara, T., Kimura, M. \& Hatanaka, T. (2012): The structural analysis and the role of calcium binding site for thermal stability in mannanase. Biochimie, 94, 2783-2790. doi: 10.1016/j. biochi.2012.09.012. Epub 2012 Sep 23.

Kumagai, Y., Usuki, H., Yamamoto, Y., Yamasato, A., Arima, J., Mukaihara, T. \& Hatanaka, T. (2011): Characterization of calcium ion sensitive region for $\beta$-mannanase from Streptomyces thermolilacinus. Biochim. Biophys. Acta, 1814, 1127-1133. doi: 10.1016/j.bbapap.2011.04.017. Epub 2011 May 12.

LaO, G., Ghangas, G.S., Jung, E.D. \& Wilson, D.B. (1991): DNA sequences of three beta-1,4-endoglucanase genes from Thermomonospora fusca. J. Bacteriol., 173, 3397-3407.

Lykidis, A., Mavromatis, K., Ivanova, N., Anderson, I., Land, M., DiBartolo, G., Martinez, M., Lapidus, A., Lucas, S., Copeland, A., Richardson, P., Wilson, D.B. \& Kyrpides, N. (2007): Genome sequence and analysis of the soil cellulolytic actinomycete Thermobifida fusca YX. J. Bacteriol., 189, 2477-2486.

Madden, T.L., Tatusov, R.L. \& Zhang, J. (1996): Applications of network BLAST server. Methods Enzymol., 266, $131-141$.

Mitchell, A., Chang, H.Y., Daugherty, L., Fraser, M., Hunter, S., Lopez, R., McAnulla, C., McMenamin, C., Nuka, G., Pesseat, S., Sangrador-Vegas, A., Scheremetjew, M., Rato, C., Yong, S.Y., Bateman, A., Punta, M., Attwood, T.K., Sigrist, C.J., Redaschi, N., Rivoire, C., Xenarios, I., Kahn, D., Guyot, D., Bork, P., Letunic, I., Gough, J., Oates, M., Haft, D., Huang, H., Natale, D.A., Wu, C.H., Orengo, C., Sillitoe, I., Mi, H., TномAs, P.D. \& FinN, R.D. (2015): The InterPro protein families database: the classification resource after 15 years. Nucleic Acids Res., 43, D213-D221.

Moraïs, S., Barak, Y., Hadar, Y., Wilson, D.B., Shoham, Y., Lamed, R. \& Bayer, E.A. (2011): Assembly of xylanases into designer cellulosomes promotes efficient hydrolysis of the xylan component of a natural recalcitrant cellulosic substrate. MBio., 2, 233-211. doi: 10.1128/mBio.00233-11. Print 2011.

Moraïs, S., Salama-Alber, O., Barak, Y., Hadar, Y., Wilson, D.B., Lamed, R., Shoham, Y. \& Bayer, E.A. (2012): Functional association of catalytic and ancillary modules dictates enzymatic activity in glycoside hydrolase family $43 \beta$-xylosidase. J. Biol. Chem., 287, 9213-9221. doi: 10.1074/jbc.M111.314286. Epub 2012 Jan 23.

O'FarRell, P.H. (1975): High resolution two-dimensional electrophoresis of proteins. J. Biol. Chem., 250, $4007-$ 4021.

Posta, K., BéKI, E., Wilson, D.B., KuKolya, J. \& Hornok, L. (2004): Cloning, characterization and phylogenetic relationships of cel5B, a new endoglucanase encoding gene from Thermobifida fusca. J. Basic Microb., 44, 383-399.

Reddy, T.B.K., Thomas, A.D., Stamatis, D., Bertsch, J., Isbandi, M., Jansson, J., Mallajosyula, J., Pagani, I., Lobos, E.A. \& KyrPides, N.C. (2015): The Genomes OnLine Database (GOLD) v.5: a metadata management system based on a four level (meta)genome project classification. Nucleid Acids Res., 43, 1099-1106.

Sakon, J., Irwin, D., Wilson, D.B. \& Karplus, P.A. (1997): Structure and mechanism of endo/exocellulase E4 from Thermomonospora fusca. Nat. Struct. Biol., 4, 810-818.

Spezio, M., Wilson, D.B. \& Karplus, P.A. (1993): Crystal structure of the catalytic domain of a thermophilic endocellulase. Biochemistry, 32, 9906-9916.

Spiridonov, N.A. \& WiLson, D.B. (2001): Cloning and biochemical characterization of BglC, a beta-glucosidase from the cellulolytic actinomycete Thermobifida fusca. Curr Microbiol., 42, 295-301.

Taylor, J.S., Teo, B., Wilson, D.B. \& BRAdy, J.W. (1995): Conformational modeling of substrate binding to endocellulase E2 from Thermomonospora fusca. Protein Eng., 8, 1145-1152.

Tóth, Á., Barna, T., Nagy, I., Horváth, B., Táncsics, A., Kriszt, B., Baka, E., Fekete, Cs. \& Kukolya, J. (2013): Draft genome sequence of the lignocellulose decomposer Thermobifida fusca strain TM51. Genome announcements, 1(4), e00482-13.

Walter, S., Wellmann, E. \& Schrempf, H. (1998): The cell wall-anchored Streptomyces reticuli avicel-binding protein (AbpS) and its gene. J. Bacteriol., 180, 1647-1654.

Wei, Y.T., Zhu, Q.X., Luo, Z.F., Lu, F.S., Chen, F.Z., Wang, Q.Y., Huang, K., Meng, J.Z., Wang, R. \& Huang, R.B. (2004): Cloning, expression and identification of a new trehalose synthase gene from Thermobifida fusca genome. Acta Biochim. Biophys. Sin. (Shanghai), 36, 477-484.

Wilson, D.B. (2004): Studies of Thermobifida fusca plant cell wall degrading enzymes. Chem. Rec., 4, 72-82.

YANG, C.H., YANG, S.F. \& Liv, W.H. (2007): Production of xylooligosaccharides from xylans by extracellular xylanases from Thermobifida fusca. J. Agr. Food Chem., 55, 3955-3959.

YANG, C.H. \& LIU, W.H. (2007): Cloning and characterization of a maltotriose-producing alpha-amylase gene from Thermobifida fusca. J. Ind. Microbiol. Biot., 34, 325-330. 
YAnG, L.L., TANG, S.K., Zhang, Y.Q., Zhi, X.Y., WANG, D., Xu, L.H. \& Li, W.J. (2008): Thermobifida halotolerans sp. nov., isolated from a salt mine sample, and emended description of the genus Thermobifida. Int. J. Syst. Evol. Microb., 58, 1821-1825.

Zhang, S. \& Wilson, D.B. (1997): Surface residue mutations which change the substrate specificity of Thermomonospora fusca endoglucanase E2. J. Biotechnol., 57, 101-113.

Zhang, S., LAO, G. \& Wilson, D.B. (1995): Characterization of a Thermomonospora fusca exocellulase. Biochemistry, 34, 3386-3395.

Zhang, Z., Wang, Y. \& Ruan, J. (1998): Reclassification of Thermomonospora and Microtetraspora. Int. J. Syst. Bacteriol., 48, 411-422. 